\title{
SIKAP PENUMPANG GARUDA INDONESIA TERHADAP TRAY-SET GREEN PRODUCT
}

Ghita Yasaningthias

Institut Ilmu Sosial dan Manajemen STIAMI

Email : ghita1.yasa@gmail.com

Keywords:

Tray-Set Green Product, Konjoint, SEM
The purpose of this study was to analyze the relationship between the attitude toward the behavior (ATB) of using the tray set green product to the intention of using the tray-set green product, to analyze the relationship between the subjective norms (SN) to the intention of using the tray-set green product, to analyze the relationship between the perceived behavioral control $(P B C)$ to the intention of using the tray-set green product, to analyze the consumers' attitudes toward the preferences of the desired attributes of the tray-set green product and to formulate the managerial implications which can be applied by PT Garuda Indonesia. The data collection was conducted in July - August 2012. Data was collected from 200 respondents who had used the services of PT Garuda Indonesia. Descriptive, Konjoint, and Structural Equation Modeling (SEM) was used to analyze the relationship between ATB, SN and PBC to the interest of using tray-set green product. The result of the study indicated that the attitude Toward Behavior, Subjective norms, perceive behavioral control had significant value to the interest. The attributive preferences desired from the tray-set green product are stronger materials, eco-friendly packaging and interesting shapes. The result of this study recommended that to improve the marketing mix strategies to enhance the passengers' interest in using tray-set green product.

\section{PENDAHULUAN}

Perusahaan menjalankan bisnis untuk menghasilkan barang dan jasa yang diperlukan oleh konsumen. Barang dan jasa yang dihasilkan tentunya harus sesuai dengan keinginan dan harapan konsumen. Terkait dengan masalah lingkungan yang semakin memburuk, perusahaan saat ini sudah mulai memperhatikan kegiatan produksinya untuk meminimalisasi pencemaran dan menciptakan produk ramah lingkungan. Selain itu, berkaitan dengan dampak produksi dan konsumsi yang dilakukan dan berkembangnya arus globalisasi juga membuat konsumen semakin baik di dalam menilai dan memilih barang dan jasa yang dihasilkan oleh perusahaan.

Masalah lingkungan tentunya akan menjadi trend perusahaan di dalam menjalankan bisnisnya. Selain itu, kemajuan Iptek akan menunjang kepada ekonomi yang berwawasan lingkungan. Teknologi back to nature atau ramah lingkungan akan diaplikasikan terhadap barang dan jasa dan mengarah kepada keberhasilan produk Iptek tersebut. Produk yang tidak ramah lingkungan seperti plastik banyak digunakan di dalam kehidupan sehari-hari seperti industri makanan, industri rumah tangga hingga industri dalam skala besar.

Produk ramah lingkungan yang dihasilkan ada yang bersifat komersial dan tidak komersial. Produk yang bersifat komersial dapat ditemukan di tempat-tempat yang menjual produk ramah lingkungan, misalnya modern trade. Produk yang tidak komersial tidak diperjualbelikan kepada masyarakat, misalnya perlengkapan dan peralatan yang menjadi fasilitas di kantor atau cabin pesawat.

Salah satu perusahaan yang mewujudkan kepedulian terhadap lingkungan akibat penggunaan kemasan dari penyajian makanan dan minuman yang menghasilkan sampah yaitu Garuda Indonesia. Garuda Indonesia yang biasanya menggunakan tray-set dari bahan yang tidak ramah lingkungan akan berencana mengganti tray-set tersebut dengan tray-set green product (ramah lingkungan). Tray-set adalah seperangkat perlengkapan untuk kebutuhan di cabin dalam kegiatan penyediaan makanan dan minuman. Rencana mengganti tray-set green product tentunya tidak semudah membalikkan tangan karena diperlukan riset terhadap konsumen. Riset terhadap konsumen ini diperlukan untuk mengetahui apa yang diinginkan oleh 
penumpang yaitu dalam hal kemasan, bentuk dan bahan selain itu juga penting untuk mengetahui informasi mengenai respon positif atau negatif penumpang terhadap tray-set green product.

Pengembangan produk ramah lingkungan dengan mengembangkan tray-set dilakukan karena produk ini yang selalu digunakan untuk menyajikan makanan dan minuman kepada penumpang, menimbulkan limbah kemasan untuk beberapa perlengkapan mono use dan dalam kurun waktu tertentu perlengkapan multi use harus diganti. Produk tray-set green product ini belum diketahui oleh penumpang oleh karena itu perlu disosialisasikan agar penumpang tidak merasa asing dan kaget ketika menggunakan dan memiliki kesan yang baik terhadap produk. Walaupun suka atau tidak suka penumpang terhadap produk, mereka tentunya tidak memiliki pilihan dan tetap harus menggunakan produk tersebut. Oleh karena itu, diperlukan penelitian yang mengarahkan konsumen untuk mau berperilaku menggunakan tray-set green product agar merasa nyaman, suka dan menerima keberadaan produk tersebut.

\section{KERANGKA TEORITIS}

\section{Persepsi}

\section{a. Pengertian Persepsi}

Menurut Danger (1992) persepsi dapat didefinisikan sebagai suatu studi mengapa manusia melihat seperti yang dilakukannya dan bagaimana mereka bereaksi kepada bentuk, penampilan, keseimbangan dan warna. Suatu desain memberikan kesan pada pikiran yang jauh di luar dari apa yang kamera rekam dan desain efektif harus memperhatikan hal ini sejalan dengan seluruh faktor lainnya yang terkait termasuk pertimbangan fungsional pada suatu kemasan. "Persepsi adalah pengalaman obyek, peristiwa atau hubungan yang diperoleh dengan menyimpulkan informasi dan menafsirkan pesan (Rakhmat 2000)".

\section{b. Proses Pembentukan Persepsi}

Proses pembentukan persepsi adalah suatu proses psikologi yang dimulai dari pancaindera yaitu proses diterimanya stimulus melalui alat reseptor yang kemdian diteruskan ke pusat susunan syaraf otak sehingga seorang individu menyadari apa yang sedang dialaminya dan kemudian dapat memberi interpretasi terhadap obyek. Persepsi dalam pengertian psikologi adalah proses pencarian informasi untuk dipahami. (Sarwono 1997).

\section{c. Faktor-Faktor yang Mempengaruhi Persepsi}

Persepsi dipengaruhi oleh beberapa faktor diantaranya: (1) Ciri khas obyek stimulus yang memberikan nilai bagi orang yang mempersepsikannya dan seberapa jauh obyek tersebut dapat menyenangkan bagi sesseorang, (2) Faktor-faktor pribadi termasuk di dalamnya ciri khas individu seperti taraf kecerdasan, minat, emosional dan lain-lain, (3) Faktor pengaruh kelompok artinya respon orang lain di lingkungannya yang dapat memberikan arah ke suatu tingkah laku individu dan (4) Faktor perbedaan latar belakang tingkah laku kultur (kebiasaan) (Taufik 2000).

\section{d. Pengukuran Persepsi}

Menurut (Taufik 2000) menyatakan persepsi merupakan tingkat positif (setuju) atau negatif (tidak setuju) terhadap obyek-obyek psikologis. Karena itu persepsi hanya dapat diukur berdasarkan penyimpulanpenyimpulan yang dibuat respon seseorang secara terbuka terhadap obyek tertentu. Respon terbuka itu dapat dilihat melalui tindakan-tindakan dan pernyataan-pernyataan yang diungkapkan responden. Salah satu teknik pengukuran persepsi yang lazim digunakan adalah dengan skala Likert. Skala Likert digunakan untuk mengukur sikap, pendapat dan persepsi seseorang terhadap obyek sikap (Sugiyono 1999).

\section{e. Preferensi}

Kotler (1997) mendefinisikan bahwa preferensi konsumen merupakan pilihan suka atau tidak suka yang dilakukan oleh seseorang terhadap produk atau jasa yang dikonsumsi. Preferensi konsumen dapat pula 
diartikan sebagai kesukaan, pilihan atau sesuatu yang lebih disukai oleh konsumen sehingga preferensi dapat terbentuk dari pemahaman dan ingatan konsumen melalui persepsi produk (Assael 1995).

\section{Sikap}

\section{a. Pengertian Sikap}

Sikap konsumen adalah salah satu studi di dalam perilaku konsumen. Schiffman dan Kanuk (1997) dalam Simamora (2002) mendefinisikan sikap sebagai ekspresi perasaan (inner feeling) yang mencerminkan apakah seseorang senang atau tidak senang, suka atau tidak suka, setuju atau tidak setuju terhadap suatu obyek.

\section{b. Fungsi Sikap}

Intinya, dalam perilaku konsumen sikap diartikan sebagai efek atau reaksi konsumen terhadap suatu produk. Sikap mempunyai empat fungsi (Hawkins et al. 2001) yaitu: 1) Fungsi Pengetahuan (Knowledge Function), 2) Fungsi Ekspresi Nilai (Value -Expressive Function), 3) Fungsi Utilitarian (Utilitarian Function), 4) Fungsi Mempertahankan Ego (Ego-Defensive Function) dan 5) Karakteristik Sikap

\section{c. Komponen Sikap}

Peter dan Olson (2010) mengemukakan Model Analisis Konsumen yang disebut sebagai Tiga Unsur Analisis Konsumen (Three Elements of Consumer Analysis). Ketiga unsur tersebut adalah consumer affect dan cognition, consumer behavior, serta consumer environment.

\section{d. Persepsi dan Sikap Responden}

Analisis persepsi dan sikap dapat dipandang sebagai posisi tray-set green product dalam ruang interpretasi dan konsep di mata konsumen. Hal ini juga dikemukakan oleh Mowen dan Minor (1998) mendefinisikan persepsi sebagai suatu proses di mana individu-individu terekspos pada informasi, menyediakan kapasitas prosesor yang lebih luas dan mampu menginterpretasikan informasi tersebut kemudian Peter dan Olson (2002) menyatakan bahwa sikap merupakan evaluasi konsep secara meyeluruh yang dilakukan seseorang. Perhitungan variabel persepsi dilakukan menggunakan skala pengukuran interval dengan instrumen pertanyaan menggunakan skala likert.

\section{e. Teori Perilaku Terencana (Theory of Planned Behaviour)}

Theory of Planned Behavior Model (TPB) adalah model sikap yang dikembangkan dari model sikap TRA (Theory of Reasoned Action). (Sumarwan 2011).

\section{Minat}

Mowen dan Minor (1998) menjelaskan bahwa minat berperilaku (behavioral intentions) adalah kecenderungan atau minat seseorang untuk berperilaku dengan cara tertentu yang bertujuan untuk mendapatkan, menggunakan ataupun melakukan pembuangan terhadap produk ataupun jasa.

\section{Produk}

\section{a. Konsep Produk}

Produk adalah apapun yang dapat ditawarkan kepada pasar untuk memuaskan permintaan atau kebutuhan (Kotler 2000). Produk merupakan variabel penting dalam bauran pemasaran karena produklah yang berhubungan langsung dengan konsumen. Perusahaan harus memiliki strategi agar produk yang dikeluarkan dapat menarik minat konsumen.

\section{b. Perencanaan Produk}

Perusahaan di dalam merencanakan produk tentunya harus memperhatikan manfaat yang akan diperoleh oleh konsumen atau pengguna produk. Perencanaan produk oleh perusahaan meliputi penciptaan produk- 
produk baru untuk memenuhi kebutuhan lama dan kebutuhan baru, perubahan-perubahan pada produk lama memiliki tujuan untuk membuatnya sesuai dengan perubahan sesuai permintaan konsumen, saran-saran atau pertambahan-pertambahan atau penarikan lini produk dalam rangka usaha untuk mencapai keuntungan yang lebih besar.

\section{c. Fungsi Kemasan}

Berdasarkan Evans dan Berman (1997), kemasan memiliki beberapa fungsi diantaranya adalah 1) Wadah dan perlindungan (protection and containtment), 2) Pemakaian (usage), 3) Komunikasi (communication), 4) Segmentasi (segmentation), 5) Hubungan kerja sama (channel cooperation), 6) Perencanaan produk baru (new product planning).

\section{d. Riset Pemasaran}

Menurut Wirya (1999) terdapat beberapa riset yang hendaknya dilakukan sebelum melakukan proses desain kemasan adalah ; 1)Riset Internal, 2) Riset Ekonomi, 3) Riset teknis, 4) Riset pasar, 5) Riset pesaing, 6) Riset konsumen, 7) Riset trend dan 8)Riset distributor atau pengecer

\section{e. Dimensi kualitas produk}

Adapun dimensi yang dapat dipergunakan dalam pengukuran kualitas produk berdasarkan Mowen dan Minor (1998) dalam Sumarwan (2002) adalah: 1)Fungsi (Performance), 2) Fitur (Features), 3) Keandalan (Reliability), 4) Usia produk (Durability), 5) Estetika (Aesthetics), 6) Pelayanan (Serviceablity) dan 7) Persepsi Kualitas (Perceived Quality)

\section{f. Persepsi Kualitas (Perceived Quality)}

Pengukuran-pengukuran dikelompokkan dalam lima kategori. Empat kategori yang pertama mewakili persepsi konsumen tentang suatu merek melalui empat dimensi ekuitas merek, yaitu loyalitas, persepsi kualitas, asosiasi dan kesadaran (loyalty, perceived quality, associations, and awareness). Secara lengkap kelima kategori tersebut adalah awareness measures, associations measures, perceived quality, loyalty measures dan market behaviour measures.

\section{g. Strategi Desain Kemasan}

Menurut Wirya dalam Purnama (2001) ada beberapa hal yang harus diperhatikan dalam menyusun strategi yang kreatif dan inovatif, diantaranya adalah 1)Warna, 2) Bentuk, 3) Ilustrasi, 4) Tipografi dan 5)Tata Letak.

\section{h. Label}

Menurut Kotler (2000) label adalah sebuah tanda sederhana yang dilekatkan pada produk atau sebuah desain grafis yang merupakan bagian dari kemasan. Label memuat informasi-informasi penting untuk memudahkan konsumen memahami manfaat dan fungsi produk.

\section{KERANGKA PEMIKIRAN}

Isu Lingkungan terkait dengan banyaknya limbah yang dihasilkan, saat ini semakin marak dibicarakan. Oleh karena itu Trend "Back to Nature" mulai muncul karena dianggap dapat menjadi solusi dari permasalahan ini. Perilaku menggunakan tray-set gren product dapat diketahui dengan menggunakan Theory of Planned Behavior (Teori Perilaku Terencana). Alur penelitian dapat dilihat pada Gambar berikut: 


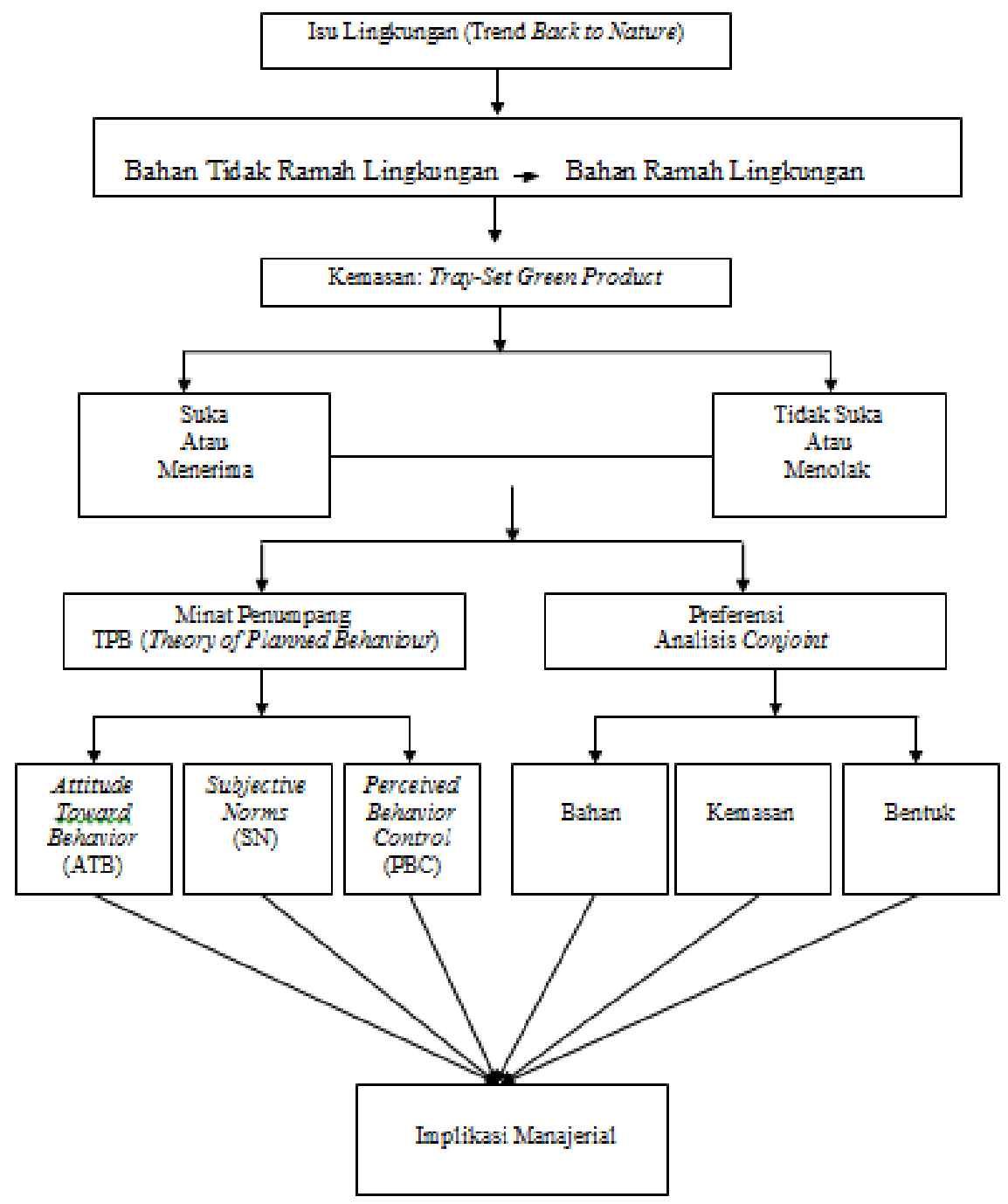

Gambar 7 Kerangka pemikiran konseptual

\section{Kerangka Pemikiran Operasional}

Analisis untuk mengetahui pengaruh hubungan sikap terhadap perilaku menggunakan tray-set green product terhadap minat (intention) menggunakan tray-set green product dengan menggunakan Analisis Structural Equation Modelling (SEM). Berdasarkan hasil pengukuran, kemudian menjadi implikasi manajerial sebagai bahan alternatif kebijakan bagi perusahaan di masa yang akan datang. Selanjutnya pada Gambar berikut disajikan kerangka pemikiran operasional sebagai berikut: 

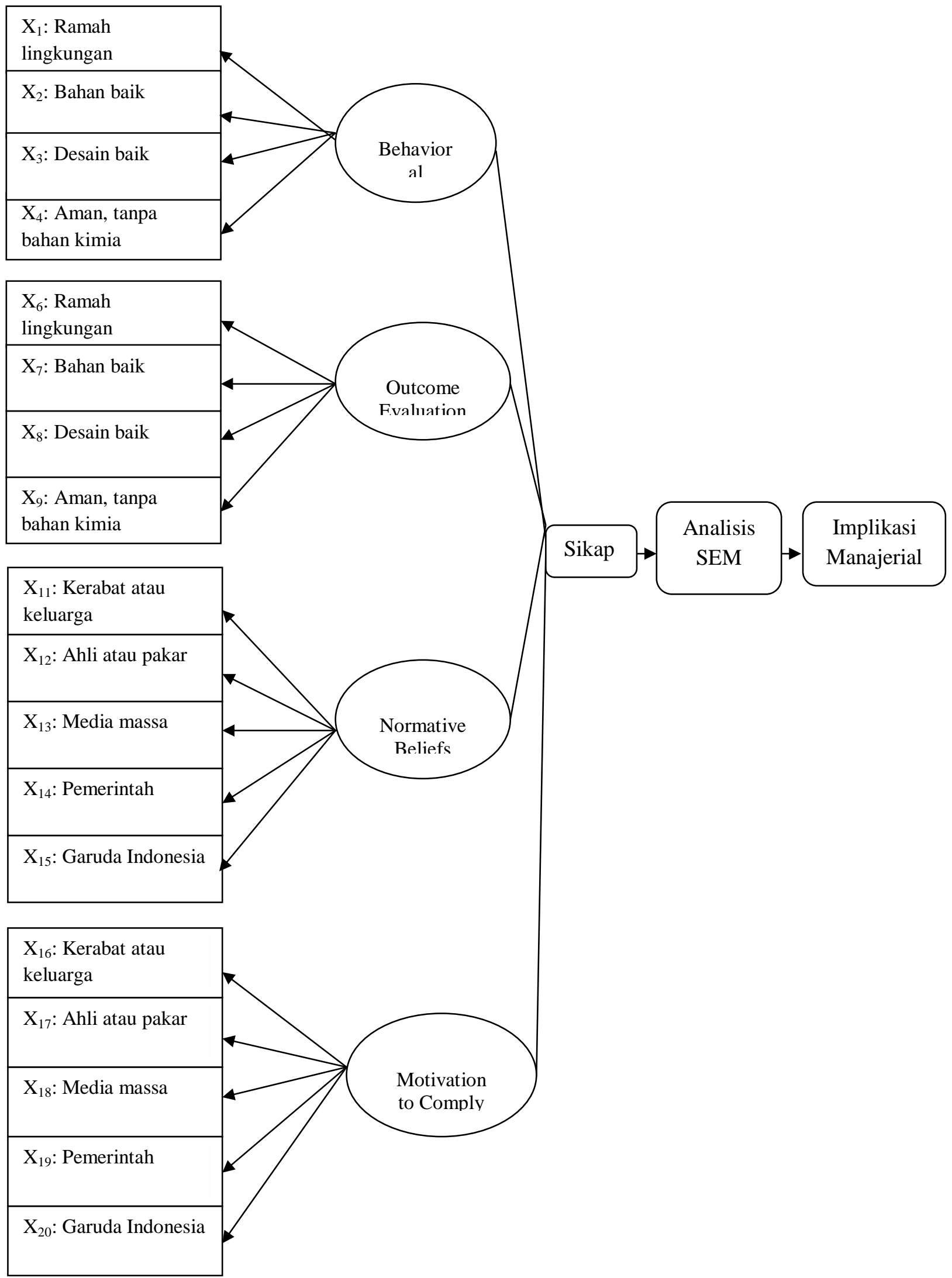


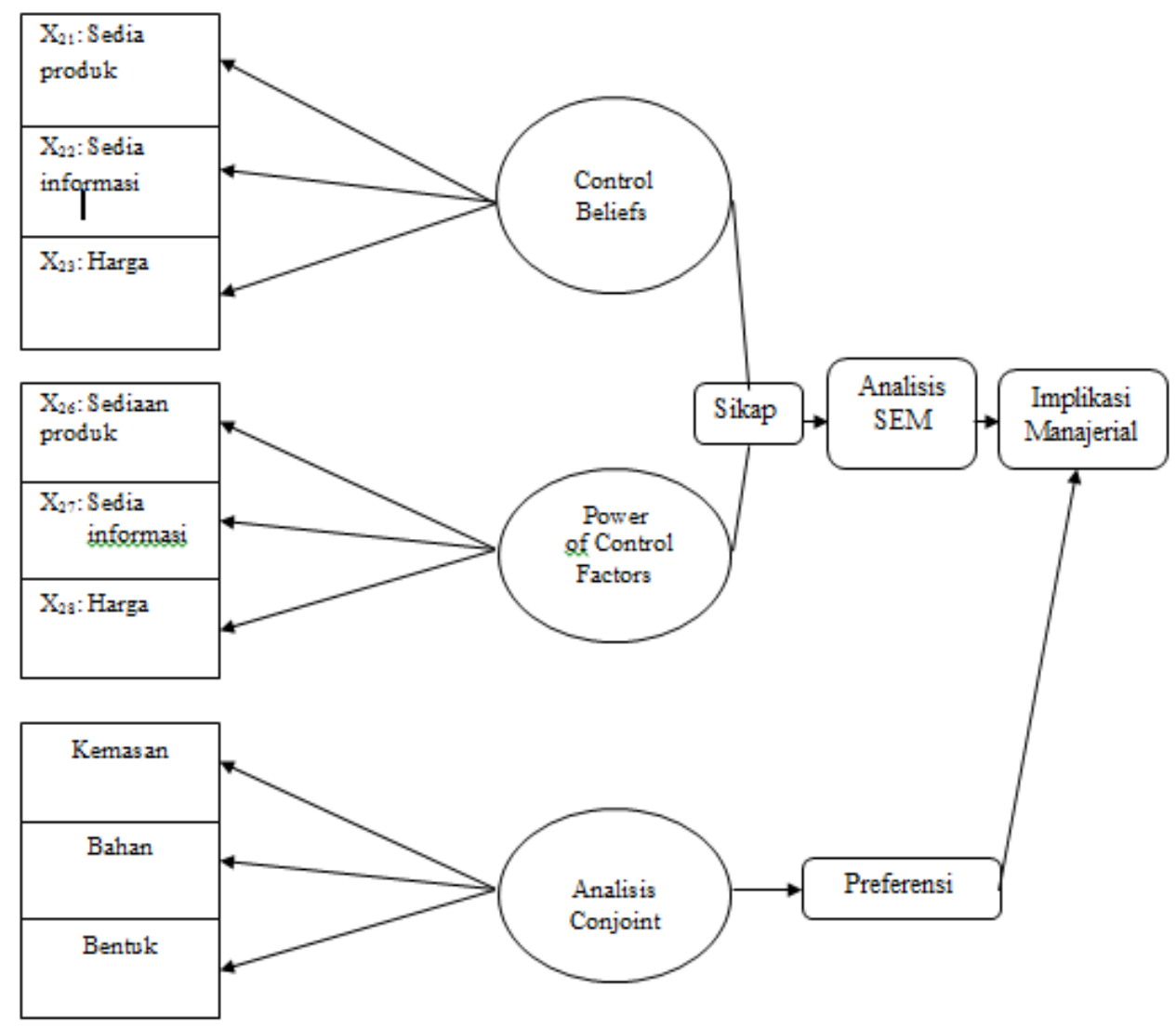

Gambar. 8 Kerangka pemikiran operasional

\section{Metodologi}

\section{Lokasi dan Waktu Penelitian}

Penelitian dilaksanakan di Bandara Soekarno-Hatta, Cengkareng dengan lokasi pengambilan contoh di Terminal 2F. Terminal 2F diambil sebagai lokasi pengambilan contoh karena digunakan untuk penerbangan domestik oleh Garuda Indonesia. Penelitian ini telah dilakukan pada bulan Juli sampai dengan Agustus 2012.

\section{Pendekatan Penelitian}

Metode penelitian yang digunakan dalam penelitian ini adalah metode deskriptif dengan menggunakan teknik survei sebagai metode pengumpulan data.

\section{Data yang Diperlukan dan Sumbernya}

Jenis data yang digunakan dalam penelitian ini adalah data primer dan data sekunder yang berasal dari dalam dan luar perusahaan yang bersifat kualitatif maupun kuantitatif. Pengumpulan data dilakukan dengan Penelitian lapangan (Field research) dan Penelitian Kepustakaan (Library research). Penelitian lapang terbagi 2 yaitu Wawancara, dan Kuesioner

\section{Teknik Pengumpulan Data dan Informasi}

Teknik pengumpulan data dalam penelitian ini dilakukan dengan menggunakan metode wawancara secara langsung kepada responden dengan alat bantu kuesioner. Hal ini dilakukan agar mengurangi kesalahan dalam pengambilan data dan pengisian kuesioner. 


\section{Teknik Pengambilan Contoh}

Metode pengambilan contoh yang digunakan adalah metode non-probability sampling, dimana peluang untuk memilih unit contoh tidak diketahui. Dengan teknik convenience sampling, yaitu contoh diambil berdasarkan ketersediaan dan kemudahan untuk mendapatkannya (Nazir 2003).

Responden adalah penumpang Garuda Indonesia yang sedang berada di ruang boarding yang kemudian dimintai kesediaannya untuk mengisi kuesioner.

Jumlah sampel 200 orang.

\section{Teknik Pengolahan dan Analisis Data}

\section{a. Deskripsi Variabel}

Variabel-variabel penelitian pembentuk minat diterjemahkan dalam 30 variabel secara lengkap dapat dilihat pada Tabel 4 yaitu:

Tabel 4 Variabel-variabel penelitian pembentuk minat menggunakan tray-set green product

\begin{tabular}{|c|c|c|c|}
\hline Konstruk & Aspek & Atribut & Simbol \\
\hline \multirow{10}{*}{$\begin{array}{c}\text { Attitude } \\
\text { Toward } \\
\text { Behavior }\end{array}$} & \multirow{5}{*}{$\begin{array}{l}\text { Behavioral } \\
\text { Beliefs }\end{array}$} & Ramah lingkungan & $\mathrm{X}_{1}$ \\
\hline & & Bahan yang baik & $\mathrm{X}_{2}$ \\
\hline & & Desain yang baik & $\mathrm{X}_{3}$ \\
\hline & & Tidak berbahaya bagi manusia & $\mathrm{X}_{4}$ \\
\hline & & Sertifikat jaminan mutu & $\mathrm{X}_{5}$ \\
\hline & \multirow{5}{*}{$\begin{array}{l}\text { Outcome } \\
\text { Evaluation }\end{array}$} & Ramah lingkungan & $\mathrm{X}_{6}$ \\
\hline & & Bahan yang baik & $\mathrm{X}_{7}$ \\
\hline & & Desain yang baik & $\mathrm{X}_{8}$ \\
\hline & & Tidak berbahaya bagi manusia & $\mathrm{X}_{9}$ \\
\hline & & Sertifikat jaminan mutu & $\mathrm{X}_{10}$ \\
\hline \multirow{10}{*}{$\begin{array}{l}\text { Subjective } \\
\text { Norms }\end{array}$} & \multirow{5}{*}{$\begin{array}{l}\text { Normative } \\
\text { Beliefs }\end{array}$} & Kerabat ataupun anggota keluarga & $\mathrm{X}_{11}$ \\
\hline & & Ahli atau pakar & $\mathrm{X}_{12}$ \\
\hline & & Media massa & $\mathrm{X}_{13}$ \\
\hline & & Pemerintah & $\mathrm{X}_{14}$ \\
\hline & & Garuda Indonesia & $\mathrm{X}_{15}$ \\
\hline & \multirow{5}{*}{$\begin{array}{l}\text { Motivation to } \\
\text { Comply }\end{array}$} & Kerabat ataupun anggota keluarga & $\mathrm{X}_{16}$ \\
\hline & & Ahli atau pakar & $\mathrm{X}_{17}$ \\
\hline & & Media Massa & $\mathrm{X}_{18}$ \\
\hline & & Pemerintah & $\mathrm{X}_{19}$ \\
\hline & & Garuda Indonesia & $\mathrm{X}_{20}$ \\
\hline \multirow{10}{*}{\multicolumn{2}{|c|}{$\begin{array}{l}\text { Perceived Behavioral } \\
\text { Control }\end{array}$}} & Ketersediaan produk ramah lingkungan & $\mathrm{X}_{21}$ \\
\hline & & $\begin{array}{l}\text { Ketersediaan informasi kualitas produk ramah } \\
\text { lingkungan }\end{array}$ & $\mathrm{X}_{22}$ \\
\hline & & Harga & $X_{23}$ \\
\hline & & Keberadaan produk ramah lingkungan & $\mathrm{X}_{24}$ \\
\hline & & Nilai-nilai yang terkandung & $\mathrm{X}_{25}$ \\
\hline & & Ketersediaan produk ramah lingkungan & $\mathrm{X}_{26}$ \\
\hline & & $\begin{array}{l}\text { Ketersediaan informasi kualitas produk ramah } \\
\text { lingkungan }\end{array}$ & $\mathrm{X}_{27}$ \\
\hline & & Harga & $\mathrm{X}_{28}$ \\
\hline & & Keberadaan produk ramah lingkungan & $\mathrm{X}_{29}$ \\
\hline & & Nilai-nilai yang terkandung & $X_{30}$ \\
\hline \multirow{2}{*}{\multicolumn{2}{|c|}{ Intention }} & Minat di masa akan datang & $\mathrm{Y}_{1}$ \\
\hline & & Minat di dalam kehidupan sehari-hari & $\mathrm{Y}_{2}$ \\
\hline
\end{tabular}


Keyakinan tentang perilaku menggunakan tray-set green product (behavior beliefs). Keyakinan perilaku terdiri dari lima indikator yang disajikan pada Tabel 5.

Tabel 5 Indikator keyakinan perilaku menggunakan tray-set green-product

\begin{tabular}{llc}
\hline No & \multicolumn{1}{c}{ Indikator } & Simbol \\
\hline 1. & $\begin{array}{l}\text { Keyakinan bahwa tray-set green-product adalah kemasan yang } \\
\text { ramah lingkungan }\end{array}$ & $\mathrm{X}_{1}$ \\
2. $\quad \begin{array}{l}\text { Keyakinan bahwa tray-set green-product adalah kemasan yang } \\
\text { menggunakan bahan yang baik }\end{array}$ & $\mathrm{X}_{2}$ \\
3. $\quad \begin{array}{l}\text { Keyakinan bahwa tray-set green-product adalah kemasan yang telah } \\
\text { di desain dengan baik }\end{array}$ & $\mathrm{X}_{3}$ \\
4. $\quad \begin{array}{l}\text { Keyakinan bahwa tray-set green product adalah kemasan yang aman } \\
\text { dan bebas dari bahan kimia }\end{array}$ & $\mathrm{X}_{4}$ \\
5. $\begin{array}{l}\text { Keyakinan bahwa tray-set green product adalah kemasan yang } \\
\text { memiliki sertifikat atau jaminan }\end{array}$ & $\mathrm{X}_{5}$ \\
\hline
\end{tabular}

Tingkat evaluasi tentang konsekuensi berperilaku atau tidak berperilaku menggunakan tray-set green product (outcome evaluation). Evaluasi konsekuensi terdiri dari lima Indikator yang dapat dilihat pada Tabel 6.

Tabel 6 Indikator evaluasi konsekuensi berperilaku atau tidak berperilaku menggunakan tray-set green-product

\begin{tabular}{|c|c|c|}
\hline No. & Indikator & Simbol \\
\hline 1. & $\begin{array}{l}\text { Evaluasi terhadap keyakinan bahwa tray-set green-product ramah } \\
\text { lingkungan }\end{array}$ & $\mathrm{X}_{6}$ \\
\hline 2. & $\begin{array}{l}\text { Evaluasi terhadap keyakinan bahwa tray-set green-product } \\
\text { menggunakan bahan yang baik }\end{array}$ & $X_{7}$ \\
\hline 3. & $\begin{array}{l}\text { Evaluasi terhadap keyakinan bahwa tray-set green-product telah di } \\
\text { desain dengan baik }\end{array}$ & $\mathrm{X}_{8}$ \\
\hline 4. & $\begin{array}{l}\text { Evaluasi terhadap keyakinan bahwa tray-set green-product aman } \\
\text { dan bebas dari bahan kimia }\end{array}$ & $\mathrm{X}_{9}$ \\
\hline 5. & $\begin{array}{l}\text { Evaluasi terhadap keyakinan tray-set green-product bahwa harus } \\
\text { memiliki sertifikat atau jaminan mutu }\end{array}$ & $X_{10}$ \\
\hline
\end{tabular}

Keyakinan normatif tentang perilaku. menggunakan tray-set green-product (normative beliefs). Keyakinan normatif terdiri dari lima indikator yang disajikan pada Tabel 7.

Tabel 7 Indikator keyakinan normatif perilaku menggunakan tray-set green-product

\begin{tabular}{clll}
\hline No. & \multicolumn{1}{c}{ Indikator } & Simbol \\
\hline 1. & $\begin{array}{l}\text { Keyakinan akan adanya pengaruh kerabat ataupun anggota } \\
\text { keluarga untuk menggunakan tray-set } \text { green-product }\end{array}$ & $\mathrm{X}_{11}$ \\
2. & $\begin{array}{l}\text { Keyakinan akan adanya pengaruh dari ahli atau pakar } \\
\text { untuk menggunakan tray-set green-product }\end{array}$ & keluarga & $\mathrm{X}_{12}$ \\
3. & $\begin{array}{l}\text { Keyakinan akan adanya pengaruh dari media massa seperti televisi, } \\
\text { radio, koran, majalah, dan lain-lain untuk menggunakan tray-set }\end{array}$ & $\mathrm{X}_{13}$ \\
green product & $\begin{array}{l}\text { Keyakinan akan adanya pengaruh dari pemerintah untuk } \\
\text { menggunakan tray-set green-product }\end{array}$ & $\mathrm{X}_{14}$ \\
5eyakinan akan adanya pengaruh dari perusahan Garuda & $\mathrm{X}_{15}$ \\
\hline
\end{tabular}

Tingkat motivasi untuk mematuhi (motivation to comply). Motivasi untuk mematuhi mempunyai lima indikator yang dapat dilihat pada Tabel 8. 


\section{Tabel 8 Indikator motivasi untuk mematuhi}

\begin{tabular}{rlc}
\hline No & \multicolumn{1}{c}{ Indikator } & Simbol \\
\hline 1. & $\begin{array}{l}\text { Seberapa besar keinginan untuk mengikuti apa yang diinformasikan } \\
\text { oleh kerabat ataupun anggota keluarga }\end{array}$ & $\mathrm{X}_{16}$ \\
2. & $\begin{array}{l}\text { Seberapa besar keinginan untuk mengikuti apa yang diinformasikan } \\
\text { oleh ahli atau pakar }\end{array}$ & $\mathrm{X}_{17}$ \\
3. & $\begin{array}{l}\text { Seberapa besar keinginan untuk mengikuti apa yang diinformasikan } \\
\text { oleh media massa seperti televisi, radio, koran, majalah, dan lain- }\end{array}$ & $\mathrm{X}_{18}$ \\
4. $\begin{array}{l}\text { lain untuk menggunakan tray-set green product } \\
\text { Seberapa besar keinginan untuk mengikuti apa yang diinformasikan }\end{array}$ & $\mathrm{X}_{19}$ \\
5leh pemerintah & $\begin{array}{l}\text { Seberapa besar keinginan untuk mengikuti apa yang diinformasikan } \\
\text { oleh perusahaan Garuda Indonesia }\end{array}$ & $\mathrm{X}_{20}$ \\
\hline
\end{tabular}

Keyakinan kontrol untuk berperilaku menggunakan tray-set green-product (control beliefs). Keyakinan kontrol terdiri dari lima indkator yang dapat dilihat pada Tabel 9.

Tabel 9 Indikator keyakinan kontrol untuk menggunakan tray-set green-product

\begin{tabular}{clc}
\hline No. & \multicolumn{1}{c}{ Indikator } & Simbol \\
\hline 1. & $\begin{array}{l}\text { Keyakinan di dalam kemudahan mendapatkan produk ramah } \\
\text { lingkungan }\end{array}$ & $\mathrm{X}_{21}$ \\
2. & $\begin{array}{l}\text { Keyakinan terhadap informasi kualitas produk ramah lingkungan } \\
\text { Keyakinan terhadap harga produk ramah lingkungan }\end{array}$ & $\mathrm{X}_{22}$ \\
3. & $\begin{array}{l}\text { Keyakinan terhadap keberadaan dari produk ramah lingkungan } \\
\text { 4. }\end{array}$ & $\mathrm{X}_{23}$ \\
5. & produkinan terhadap nilai-nilai yang terkandung di dalam inovasi & $\mathrm{X}_{24}$ \\
& $\mathrm{X}_{25}$
\end{tabular}

Tingkat kekuatan faktor kontrol untuk berperilaku menggunakan tray-set green-product (power of control factors).

Tabel 10 Indikator kekuatan kontrol untuk berperilaku menggunakan tray-set green-product

\begin{tabular}{clc}
\hline No. & \multicolumn{1}{c}{ Indikator } & Simbol \\
\hline 1. & $\begin{array}{l}\text { Akibat dari keyakinan di dalam kemudahan mendapatkan produk ramah } \\
\text { lingkungan }\end{array}$ & $\mathrm{X}_{26}$ \\
2. & $\begin{array}{l}\text { Akibat dari keyakinan terhadap informasi kualitas produk ramah } \\
\text { lingkungan }\end{array}$ & $\mathrm{X}_{27}$ \\
3. & $\begin{array}{l}\text { Akibat dari keyakinan terhadap harga produk ramah lingkungan } \\
\text { 4. }\end{array}$ & $\mathrm{X}_{28}$ \\
& $\begin{array}{l}\text { Akibat dari keyakinan terhadap keberadaan dari produk ramah } \\
\text { 5. }\end{array}$ & $\mathrm{X}_{29}$ \\
& $\begin{array}{l}\text { Akibat dari keyakinan terhadap nilai-nilai yang terkandung di dalam } \\
\text { inovasi produk ramah lingkungan }\end{array}$ & $\mathrm{X}_{30}$ \\
\end{tabular}

Behavioral intention (minat) menggunakan tray-set green product diartikan sebagai indikasi seberapa kuat minat seseorang untuk menggunakan tray-set green product dan seberapa banyak usaha yang dilakukannya. Minat menggunakan tray-set green product diukur dengan dua pertanyaan yang dapat dilihat pada Tabel 11 .

Tabel 11 Indikator minat menggunakan tray-set green-product

\begin{tabular}{clc}
\hline No. & \multicolumn{1}{c}{ Indikator } & Simbol \\
\hline 1. & $\begin{array}{l}\text { Minat menggunakan di masa yang akan datang terhadap tray-set } \\
\text { green-product }\end{array}$ & $\mathrm{Y}_{1}$ \\
2. & $\begin{array}{l}\text { Minat menggunakan di dalam kehidupan sehari-hari terhadap } \\
\text { tray-set green-product }\end{array}$ & $\mathrm{Y}_{2}$ \\
\hline
\end{tabular}




\section{b. Analisis Deskriptif}

Analisis deskriptif merupakan transformasi data mentah ke dalam bentuk yang mudah dipahami atau diinterpretasi. Analisis deskriptif disebut juga analisis pendahuluan yang bertujuan untuk mengetahui karakteristik setiap peubah dalam contoh (Simamora 2004).

\section{c. Analisis Structural Equation Modelling (SEM)}

SEM (Structural Equation Modelling) adalah alat analisis sebagai teknik statistik multivariat dependensi yang memiliki banyak kelebihan diantara alat-alat analisis lainnya. SEM mampu menganalisis variabel laten, variabel indikator, serta mampu menghitung kesalahan pengukuran dalam model secara langsung (Sitinjak dan Sugiarto 2006).

\section{d. Analisis Konjoin (Conjoint Analysis)}

Analisis ini digunakan untuk mengetahui preferensi konsumen terhadap tray-set garuda indonesia. Analisis konjoin (conjoint analysis, considered jointly) merupakan suatu model analisis dalam analisis multivariate yang dikembangkan sejak tahun 1970. Analisis ini digunakan untuk membantu mendapatkan kombinasi atau komposisi atribut-atribut suatu produk atau jasa baik baru maupun lama yang paling disukai oleh konsumen. Secara umum model dasar analisis konjoin dapat dituliskan dalam bentuk:

$\mathrm{U}(\mathrm{X})=\sum_{i=1}^{m} \sum_{j=1}^{k i} \beta_{\mathrm{ij}} \mathrm{Xij}$

dimana:

$\mathrm{U}(\mathrm{X})=$ Utility total

$\beta_{\mathrm{ij}} \quad=$ Part worth atau nilai kegunaan dari atribut ke-i taraf ke-j

$\mathrm{k} 1 \quad=$ Taraf ke-j dari atribut ke-i

$\mathrm{m} \quad=$ Jumlah atribut

xij = Dummy variable atribut ke-i taraf ke-j (bernilai 1 bila taraf yang berkaitan muncul dan 0 bila tidak)

Tabel 13 Atribut dan taraf atribut tray-set green product yang diteliti

\begin{tabular}{cll}
\hline No & Atribut & \multicolumn{1}{c}{ Taraf Atribut } \\
\hline 1. & Kemasan & Tidak Ramah lingkungan \\
& & Ramah lingkungan \\
2. & Bahan & Tidak kuat \\
& & Kuat \\
3. & Bentuk & Tidak menarik \\
& & Menarik \\
\hline
\end{tabular}

Pada penelitian ini analisis konjoin menggunakan evaluasi banyak faktor atau yang sering disebut full profile combination. Tabel 13 berikut menunjukkan desain kombinasi dari berbagai taraf atribut tray-set green produ. 
Vol. 15, No. 1, Maret 2018, pp. 1 - 21

Tabel 14 Desain kombinasi atribut tray-set green product

\begin{tabular}{|c|c|c|c|c|}
\hline No & Kemasan & Bahan & Bentuk & Kartu \\
\hline 1 & $\begin{array}{l}\text { Tidak ramah } \\
\text { lingkungan }\end{array}$ & Tidak kuat & Tidak menarik & 1 \\
\hline 2 & $\begin{array}{l}\text { Tidak ramah } \\
\text { lingkungan }\end{array}$ & Kuat & Menarik & 2 \\
\hline 3 & $\begin{array}{l}\text { Tidak ramah } \\
\text { lingkungan }\end{array}$ & Tidak kuat & Menarik & 3 \\
\hline 4 & $\begin{array}{l}\text { Tidak ramah } \\
\text { lingkungan }\end{array}$ & Kuat & Tidak menarik & 4 \\
\hline 5 & Ramah lingkungan & Kuat & Menarik & 5 \\
\hline 6 & Ramah lingkungan & Tidak kuat & Tidak menarik & 6 \\
\hline 7 & Ramah lingkungan & Kuat & Tidak menarik & 7 \\
\hline 8 & Ramah lingkungan & Tidak kuat & Menarik & 8 \\
\hline
\end{tabular}

\section{Gambaran Umum Perusahaan}

\section{Sejarah PT Garuda Indonesia}

Tanggal 26 Januari 1949 terbentuklah usaha penerbangan niaga dengan nama "Indonesian Airways" dan ini menjadi lahirnya perintis penerbangan niaga nasional Bangsa Indonesia dan merupakan awal sejarah berdirinya usaha penerbangan niaga sipil di Indonesia. Tanggal 26 Januari dijadikan sebagai hari lahirnya "Garuda Indonesia" yang merupakan hari pertama dilaksanakannya usaha penerbangan niaga oleh sebuah pesawat pembawa pendera nasional Bangsa Indonesia.

\section{Visi, Misi, Tujuan dan Nilai Perusahaan PT Garuda Indonesia}

\section{a. Visi dan Misi Perusahaan}

Visi PT Garuda Indonesia yaitu menjadi perusahaan penerbangan yang handal dengan menawarkan layanan yang berkualitas kepada masyarakat dunia menggunakan keramahan Indonesia. Misi PT Garuda Indonesia yaitu sebagai perusahaan penerbangan pembawa bendera bangsa (flag carrier) Indonesia yang mempromosikan Indonesia kepada dunia guna menunjang pembangunan ekonomi nasional dengan memberikan pelayanan yang profesional.

\section{b. Tujuan dan Nilai Perusahaan}

Untuk mencapai visi perusahaan maka tujuan perusahaan adalah menjadi maskapai penerbangan terkemuka dengan reputasi yang sejajar dengan maskapai kelas dunia lainnya. Sedangkan sasaran perusahaan yang hendak dicapai adalah menciptakan perusahaan yang terus tumbuh dan berkembang dengan keuntungan yang berkelanjutan. Kemudian tata nilai perusahaan yang disebut sebagai 'Fly-Hi' terdiri dari: eFficient \& effective, Loyalty, customet centricit $\boldsymbol{Y}, \boldsymbol{H}$ onesty \& openness dan Integrity.

\section{Hasil Dan Pembahasan}

Penyebaran kuesioner yang telah dilakukan, kemudian dilakukan uji validitas dan reabilitas. Uji validitas dan reabilitas dilakukan dengan kuesioner mengenai persepsi, sikap dan niat responden. Uji dilakukan menggunakan software SAS 9.1.3. Hasil pengujian ini menunjukkan bahwa kuesioner telah memenuhi standar yang valid dan reliabel pada selang kepercayaan 95 persen. 


\section{Karakteristik Responden}

Responden yang digunakan dalam penelitian ini berjumlah 160 orang berdasarkan rumus SEM namun untuk memperoleh data yang baik maka digunakan 200 responden.

\section{Karakteristik Responden berdasarkan Demografi}

\section{a. Usia}

Berdasarkan hasil penelitian bahwa usia responden didominasi oleh usia $<25$ tahun yaitu sebanyak 42 persen, diikuti oleh usia 25-35 tahun sebanyak 32 persen, 36-45 tahun sebanyak 9 persen, 46-55 tahun sebanyak 9 persen dan $\geq 56$ tahun sebanyak 8 persen. Kelompok usia $<25$ tahun merupakan usia tergolong dewasa yang menggunakan maskapai penerbangan.

\section{b. Jenis Kelamin}

Berdasarkan hasil pengambilan responden yang berjumlah 200 orang, sebanyak 54 persen adalah pria. Hal ini menunjukkan bahwa di dalam penelitian jenis kelamin pria dominan di dalam pengisian kuesioner ini.

\section{Analisis Model Struktural Niat Penumpang Garuda Indonesia untuk Menggunakan Produk Ramah Lingkungan yaitu Tray-Set Green Product dengan Structural Equation Modelling (SEM)}

Hasil yang diperoleh di dalam penelitian ini yaitu nilai Chi-Square/df sebesar 1.05 dengan cutt off value $\leq 3.00$ sehingga model di dalam penelitian ini dikatakan memenuhi ( good fit). Kecocokan keseluruhan model (overall model fit) dapat dilihat apabila memiliki nilai chi-square yang rendah. Nilai chi-square yang semakin rendah menandakan bahwa model tersebut semakin baik. Hal ini disebabkan karena dalam uji beda chi-square, nilai $\chi^{2}=0$, berarti benar-benar tidak ada perbedaan dan $\mathrm{H}_{0}=$ diterima berdasarkan probabilitas (p-value) dengan cut-off value sebesar $\mathrm{p}>0.05$.

GFI (Goodness of Fit Index) adalah sebuah ukuran non statistikal yang memiliki rentang nilai antara 0 (poor fit) sampai dengan 1.0 (perfect fit). Nilai yang tinggi dalam indeks ini menunjukkan model tersebut better fit. Berdasarkan hasil analisis diperoleh nilai GFI sebesar 0.98 sehingga model di dalam penelitian ini termasuk dalam kategori good fit. Berdasarkan penelitian diperoleh nilai AGFI sebesar 0.97, hal ini menandakan bahwa model dapat diterima dengan tingkatan yang baik.

RMSEA (Root Mean Square Error of Approximation) adalah indeks yang dapat digunakan untuk mengkompensasi chi-square statistic dalam sampel yang besar (Baumgartner dan Homburg 1996 dalam Ferdinand 2005). Nilai RMSEA menunjukkan goodness of fit yang dapat diharapkan bila model diestimasi dalam populasi (Hair et al. 1995 dalam Ferdinand 2005). Nilai RMSEA yang lebih kecil atau sama dengan 0,08 merupakan syarat diterimanya model yang menunjukkan kriteria close fit arti model tersebut berdasarkan degress of freedom (Browne dan Cudect 1993 dalam Ferdinand 2005). Berdasarkan penelitian diperoleh nilai RMSEA sebesar 0.01, hal ini menandakan bahwa bahwa model dapat diterima. Indeks kesesuaian (fit index) ini akan menghitung proporsi tertimbang dari varians dalam matriks kovarian sampai yang dijelaskan oleh matriks kovarians populasi yang terestimasikan (Bentler 1983; Tanaka dan Huba 1989 dalam Ferdinand 2005).

Berdasarkan hasil yang diperoleh, keseluruhan model yang dibangun memiliki nilai yang sesuai (Goodness of Fit Statistics) yaitu model struktural telah memenuhi kriteria yang ditetapkan sehingga model yang dibangun dapat menjelaskan informasi empiris sesuai data yang dikumpulkan. Hal ini menunjukkan bahwa bahwa model yang telah ditetapkan dapat digunakan dalam menilai niat penumpang terhadap variabel-variabel indikator yang digunakan.

Hasil pengujian menunjukkan bahwa variabel laten eksogen ATB dan SN memiliki hubungan yang signifikan dalam membentuk variabel intention (minat) karena nilai uji-t masing variabel laten tersebut lebih besar dari 1.96 .

Untuk variabel indikator eksogen $\mathrm{X}_{1}$ sampai dengan $\mathrm{X}_{28}$ semuanya memiliki nilai uji-t yang lebih besar dari 1.96 sehingga variabel-variabel indikator tersebut memiliki hubungan yang signifikan terhadap masingmasing variabel latennya. Pada variabel indikator $Y_{1}$ sampai dengan $Y_{2}$, memiliki nilai uji-t yang dari 1.96, 
yang berarti bahwa variabel-variabel indikator tersebut memiliki hubungan yang signifikan terhadap masing-masing variabel latennya.

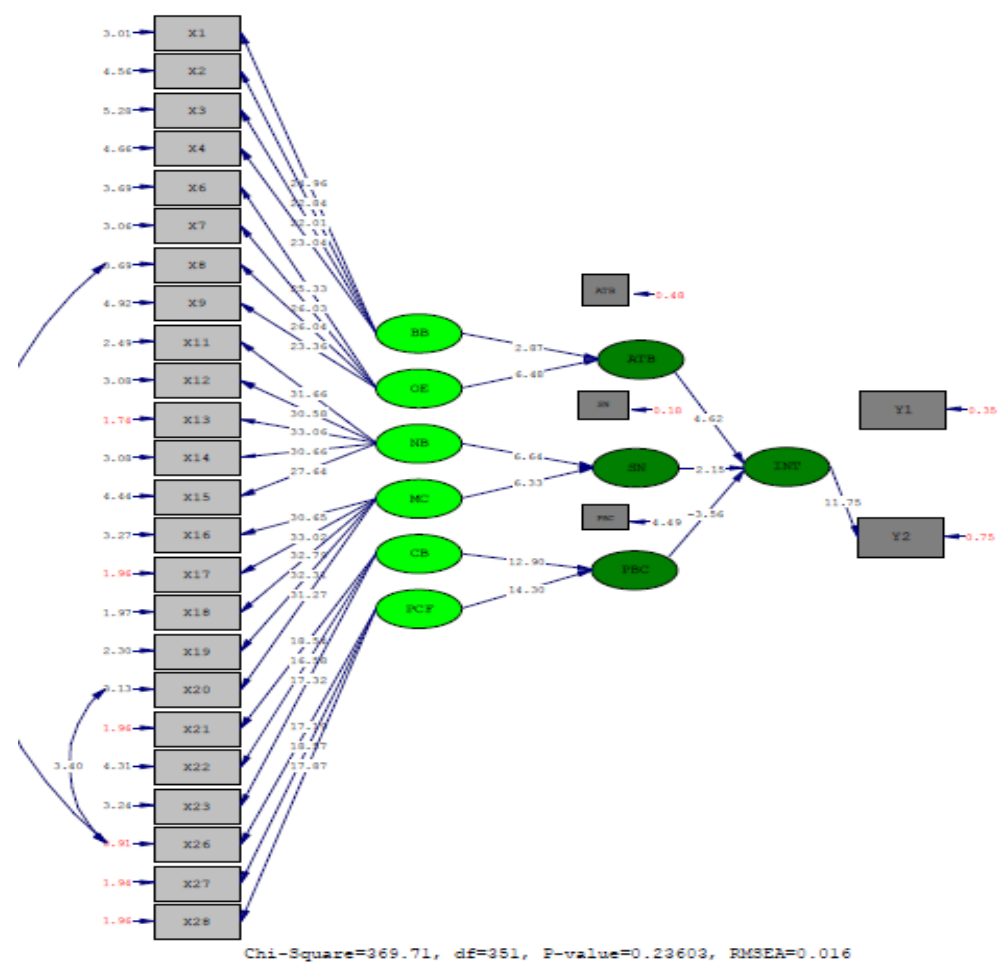

Gambar 11 Uji signifikansi (t-test) model SEM hasil olahan

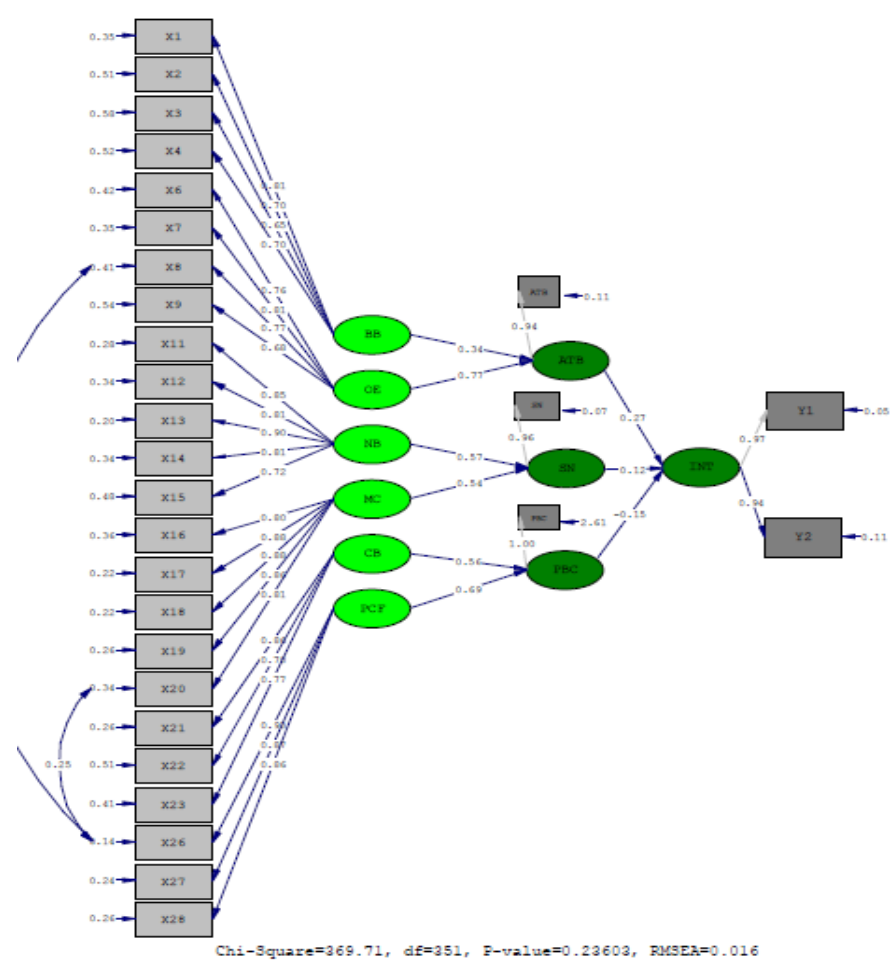

Gambar 12 Standardized loading factor model SEM hasil olahan

\section{Uji Kecocokan Model Pengukuran}

Nilai faktor muatan seluruhnya memiliki validitas yang baik, dimana dapat dikatakan variabel indikator secara tepat mampu mengukur konstruk yang dimaksud. 
Uji reliabilitas yang menjelaskan kekonsistensian variabel indikator dilihat dari Construct Reliability (CR) dan Variance Extracted (VE). Variabel-variabel indikator pada konstruk laten NB, MtC, CB, dan BI memiliki reliabilitas yang baik, karena memiliki nilai CR lebih besar dari 0.7 dan VE lebih besar dari 0.5. Hal tersebut menunjukkan bahwa variabel-variabel indikator yang ada pada konstruk laten tersebut mampu memberikan informasi yang diinginkan dan dapat dipercaya (diandalkan) dalam memberikan hasil yang relatif sama (konsisten) apabila dilakukan pengukuran kembali

\section{Uji Kecocokan Model Struktural}

Pada penelitian ini uji signifikansi menggunakan tingkat signifikansi 0.05 (tingkat kepercayaan 95 persen). Maka pada tingkat signifikansi 0.05 nilai-T dari setiap koefisien persamaan struktural harus lebih besar daripada 1.96. Nilai uji-T yang lebih kecil dari 1.96 menunjukkan terdapat hubungan yang tidak signifikan ataupun tidak dapat menjelaskan variabel laten yang dituju oleh anak panah

\section{Pengaruh Behavioral Beliefs (BB) dengan Variabel Indikatornya}

Variabel laten eksogen BB (keyakinan terhadap perilaku menggunakan tray-set green product) memiliki empat indikator. Indikator tersebut yaitu keyakinan akan menjaga kelestarian lingkungan (BB1), keyakinan akan produk terbuat dari bahan yang baik (BB2), keyakinan akan produk di desain dengan baik (BB3), keyakinan akan produk yang aman dan bebas dari bahan kimia (BB4).

Keyakinan terhadap menggunakan produk ini akan mampu untuk ikut menjaga kelestarian lingkungan (BB1) merupakan variabel indikator yang paling besar nilainya (0.81) bagi kontribusi pembentuk konstruk BB. Responden meyakini bahwa dengan menggunakan tray-set green product maka dirinya telah memberikan kontribusi terhadap kelestarian lingkungan. Hasil tersebut sejalan dengan penelitian yang dilakukan oleh Mei (2009) yang menyatakan bahwa sikap kesadaran akan lingkungan adalah faktor yang mempengaruhi konsumen dalam pembelian makanan organik. Walaupun ini terhadap makanan organik tetapi pada dasarnya masyarakat sebenarnya telah memiliki kesadaran terhadap pentingnya "Go Green" itu sudah tercipta. Sementara itu, variabel indikator yang memiliki faktor muatan paling rendah (0.65) yaitu keyakinan akan produk tray-set green product mengenai performance (penampilan) yang di desain lebih baik bila dibandingkan dengan tray set non green product (BB3) memiliki kontribusi yang kecil terhadap pembentukan konstruk BB. Tray-set merupakan wadah makanan dan minuman yang cenderung memiliki penampilan (bentuk fisik dan fungsi) yang sama untuk semua jenis bahan pembentuknya, sehingga hal tersebut membuat responden memiliki keyakinan bahwa penampilan tray set green product akan di desain sama saja dengan tray set non green product.

\section{Pengaruh Outcome Evaluation (OE) dengan Variabel Indikatornya}

Variabel laten eksogen OE (evaluasi terhadap keyakinan terhadap perilaku menggunakan tray set green product) memiliki empat indikator. Indikator tersebut yaitu konsekuensi dari keyakinan akan menjaga kelestarian lingkungan (OE6), konsekuensi dari keyakinan akan produk terbuat dari bahan yang baik (OE7), konsekuensi dari keyakinan akan produk di desain dengan baik (OE8), konsekuensi dari keyakinan akan produk aman dan bebas dari bahan kimia (OE9).

Berdasarkan hasil penelitian menunjukkan bahwa variabel indikator konsekuensi keyakinan dari produk terbuat dari bahan yang baik (OE7) memiliki nilai faktor muatan yang paling besar (0.81) diantara ketiga variabel indikator yang lain. Hasil penelitian menyatakan bahwa kesadaran akan kesehatan akan mempengaruhi sikap konsumen dalam pembelian makanan organik. Hal ini juga menunjukkan bahwa memang kesehatan tubuh yang didapatkan setelah membeli dan mengkonsumi tray set green product merupakan hal yang paling diharapkan oleh responden. Pentingnya kesehatan juga menunjukkan bahwa kesadaran akan pentingnya "Go Green" terutama gaya hidup sehat telah tercipta. Sementara itu, variabel indikator yang memiliki faktor muatan terendah (0.68) adalah konsekuensi dari keyakinan produk yang aman dan bebas dari bahan kimia (OE9). Hal tersebut menunjukkan bahwa memang produk yang aman dan bebas dari bahan kimia pada tray set green product memang bukan merupakan faktor yang dipentingkan oleh responden. 


\section{Pengaruh Normative Beliefs (NB) dengan Variabel Indikatornya}

Variabel laten eksogen NB (keyakinan terhadap adanya tekanan sosial untuk berperilaku menggunakan tray set green product dari pihak tertentu) memiliki lima variabel indikator. Indikator tersebut yaitu keyakinan bahwa kerabat (teman) ataupun anggota keluarga yang menganjurkan (NB11), keyakinan bahwa ahli atau pakar yang menganjurkan (NB12), keyakinan bahwa media massa (televisi, radio, koran, majalah dan lain-lain) yang menganjurkan (NB13), keyakinan bahwa pemerintah yang menganjurkan (NB14) dan keyakinan bahwa perusahaan Garuda Indonesia yang menganjurkan (NB15).

Keyakinan media massa (televisi, radio, koran, majalah dan lain-lain) yang menganjurkan untuk berperilaku menggunakan tray set green product (NB13) merupakan indikator yang memiliki kontribusi terbesar (0.90). Responden meyakini bahwa saat ini media massa yang memiliki peranan penting dan dominan menganjurkan responden untuk menggunakan tray set green product.

Sementara itu, variabel indikator yang memiliki faktor muatan terendah $(0.72)$ adalah keyakinan bahwa perusahaan Garuda Indonesia yang menganjurkan untuk berperilaku menggunakan tray set green product. Hal tersebut menunjukkan bahwa memang responden tidak terlalu terpengaruhi oleh indikator (NB15). Solusi dari permasalahan ini adalah perusahaan perlu membangun citra dari produk yang dikeluarkan melalui beragam cara dan program.

\section{Pengaruh Motivation to Comply (MC) dengan Variabel Indikatornya}

Variabel laten eksogen MtC (motivasi untuk mematuhi) memiliki lima indikator, yaitu mengikuti anjuran kerabat (teman) ataupun anggota keluarga (MC16), mengikuti anjuran ahli atau pakar (MC17), mengikuti anjuran media massa (televisi, radio, koran, majalah dan lain-lain) (MC18), mengikuti anjuran pemerintah (MC19) dan mengikuti anjuran perusahaan Garuda Indonesia (MC20).

Mengikuti anjuran ahli atau pakar (MC17) dan media massa (televisi, radio, koran, majalah dan lainlain) (MC18) merupakan dua variabel indikator yang memiliki nilai paling besar (0.88) bagi kontribusi konstruk MtC. Responden merasa bahwa mengikuti anjuran ahli atau pakar dan media massa merupakan hal utama yang mendorong untuk berperilaku menggunakan tray set green product. Respondent memberikan sikap yang positif dalam memandang dan menilai media massa sebagai sarana yang mampu memberikan sejumlah informasi. Selain itu, media massa juga suka dilengkapi dengan penampilan atau atraksi yang menarik, penataan suara dan warna yang harmonis serta pesan dan informasi yang lengkap. Sementara itu, variabel indikator yang memiliki kontribusi terendah (0.80) adalah mengikuti anjuran kerabat (teman) ataupun anggota keluarga. Hal ini menunjukkan bahwa responden tidak terlalu memperhatikan anjuran kerabat (teman) ataupun anggota keluarga. Selain itu, juga dapat disebabkan diantara kerabat (teman) ataupun anggota keluarga kurang terjadi sharing informasi.

\section{Pengaruh Control Beliefs (CB) dengan Variabel Indikatornya}

Variabel laten eksogen CB (kepercayaan kontrol) memiliki tiga indikator, yaitu persepsi produk ramah lingkungan yang sulit diperoleh (CB21), persepsi ketersedian informasi mengenai kualitas produk ramah lingkungan yang belum banyak (CB22), dan persepsi produk ramah lingkungan yang harganya relatif lebih mahal (CB23). Variabel indikator CB21 memiliki kontribusi paling besar $(0,86)$ dan indikator CB 22 memiliki kontribusi paling kecil $(0,70)$. Hal ini menunjukkan bahwa responden lebih meyakini bahwa ketersediaan produk ramah lingkungan yang sulit diperoleh merupakan faktor penghambat atau mengurangi minat menggunakan produk ramah lingkungan dibandingkan dengan ketersediaan informasi mengenai kualitas produk ramah lingkungan yang relatif belum banyak.

\section{Pengaruh Power Control Factor (PCF) dengan Variabel Indikatornya}

Variabel laten eksogen PCF (faktor kekuatan yang mengontrol) memiliki tiga indikator, yaitu produk ramah lingkungan yang sulit diperoleh akan membuat minat menggunakan menjadi berkurang (PCF26), keterbatasan informasi mengenai kualitas produk ramah lingkungan yang relative belum banyak akan membuat minat menggunakan menjadi berkurang (PCF27) dan harga produk ramah lingkungan yang relatif lebih mahal akan membuat minat menggunakan menjadi berkurang (PCF28). Variabel indikator PCF26 memiliki kontribusi paling besar (0.93) dan indikator PCF28 memiliki kontribusi paling kecil (0.86). 
Hal ini menunjukkan bahwa responden lebih meyakini bahwa ketersediaan produk ramah lingkungan yang sulit diperoleh merupakan faktor penghambat atau mengurangi minat menggunakan produk ramah lingkungan dibandingkan dengan harga produk ramah lingkungan yang relatif lebih mahal.

\section{Pengaruh antara Attitude Toward Behavior (ATB) dengan Behavioral Beliefs (BB) dan Outcome Evaluation (OE)}

Hasil penelitian menunjukkan bahwa kepercayaan perilaku menggunakan tray set green product (BB) dan evaluasi konsekuensi terhadap perilaku menggunakan tray set green product $(\mathrm{OE})$ secara nyata dapat menjelaskan sikap terhadap perilaku menggunakan tray set green product (ATB). Konstruk BB dan OE secara nyata mempengaruhi ATB pada tingkat kepercayaan 95 persen. Faktor muatan konstruk BB adalah 0.34, dimana BB dapat menerangkan ATB sebesar 0.34. Nilai faktor muatan untuk BB hanya memberikan kontribusi yang kecil terhadap ATB. Variabel kepercayaan perilaku menggunakan tray set green product merupakan representasi dari pengetahuan responden. Pengetahuan merupakan komponen kognitif yang seringkali menentukan sikap konsumen. Hal ini menandakan bahwa pengetahuan akan kegunaan, manfaat, dan kesadaran responden dari perilaku menggunakan tray set green product masih rendah.

Faktor muatan konstruk OE (0.77) memiliki nilai yang lebih besar dari pada BB (0.34). Responden berarti mementingkan evaluasi atas keyakinan-keyakinan mengenai perilaku menggunakan tray set green product. Hal tersebut menunjukkan bahwa evaluasi konsekuensi terhadap perilaku menggunakan tray set green product $(\mathrm{OE})$ lebih penting kontribusinya dalam membentuk sikap terhadap perilaku menggunakan tray set green product (ATB) dibandingkan kepercayaan perilaku menggunakan tray set green product (BB).

\section{Pengaruh Subjective Norms (SN) dengan Normative Beliefs (NB) dan Motivation to Comply (MtC)}

Hasil penelitian menunjukkan bahwa kepercayaan atau persepsi individu adanya dorongan dari pihak-pihak tertentu untuk menggunakan tray set green product (NB) dan anjuran dari pihak-pihak tertentu untuk menggunakan tray set green product secara nyata dapat meningkatkan minat menggunakan tray set green product yang disebabkan oleh pengaruh dari pihak-pihak tertentu (SN). Konstruk NB dan MC secara nyata mempengaruhi SN pada tingkat kepercayaan 95 persen. Faktor muatan konstruk NB adalah 0.57 , dimana NB dapat menerangkan SN sebesar 0.57. Faktor muatan konstruk NB $(0,57)$ memiliki nilai yang lebih besar dari pada MC (0.54). Hal ini menandakan bahwa responden memiliki kepercayaan yang lebih besar tentang persepsi adanya dorongan dari pihak-pihak tertentu yang menginginkan untuk menggunakan tray set green product. Responden menggunakan tray set green product dipengaruhi oleh pihak tertentu seperti anggota keluarga, kerabat dan lain-lain. Tray-set green product merupakan produk yang relatif masih baru dan belum banyak dikenal. Oleh karena itu, juga diperlukan pengaruh pihak-pihak tertentu yang menganjurkan untuk menggunakan tray set green product.

\section{Pengaruh Perceived Behavioral Control (PBC) dengan Control Beliefs (CB) dan Power of Control Factor (PCF)}

Hasil penelitian menunjukkan bahwa CB dan PCF memiliki pengaruh yang signifikan terhadap PBC. Nilai faktor muatan untuk CB dan PCF masing-masing sebesar 0.56 dan 0.69. Hal tersebut menunjukkan bahwa memang terdapat faktor yang menghambat ataupun mengurangi minat dalam menggunakan tray set green product. Konstruk PCF memiliki nilai yang lebih besar dari $\mathrm{CB}$, hal tersebut menunjukkan bahwa faktor pembatas lebih penting kontribusinya dalam membentuk PBC dibandingkan dengan CB yang menunjukkan persepsi responden saat ini mengenai keberadaan hal-hal yang dapat mengurangi atau menghambat minat menggunakan tray set green product.

\section{Pengaruh antara Attitude Toward Behavior (ATB), Subjective Norms (SN) dan Perceived Behavioral Control (PBC) dengan Behavior Intention (BI)}

Hasil pengujian menunjukkan bahwa dimensi ATB, SN dan PBC secara nyata pada taraf uji 5 persen mampu menjelaskan minat menggunakan tray set green product. Sikap terhadap perilaku mengunakan tray set green product (ATB) berpengaruh secara positif terhadap minat menggunakan tray set green product. Sikap dan minat yang memiliki hubungan positif sejalan dengan hasil penelitian mengenai 
produk ramah lingkungan (go green) dilakukan oleh Tarkiainen dan Sundqvist (2005) yang menyatakan bahwa sikap terhadap pembelian makanan organik memiliki kontribusi signifikan positif terhadap pembentukan minat membeli makanan organik. Penelitian ini juga menunjukkan bahwa sikap responden yang semakin positif terhadap perilaku menggunakan tray set green product, maka akan semakin besar minat untuk menggunakan tray set green product.

Norma subjektif (SN) memiliki nilai yang signifikan pada taraf 5 persen, yaitu sebesar 0.12 . Hal menunjukkan bahwa SN mampu menjelaskan pengaruhnya terhadap minat menggunakan tray set green product. Nilai faktor muatannya sebesar 0.12 , berarti konstruk ini mampu menjelaskan BI sebesar 0.12 . Hal ini menunjukkan bahwa pihak-pihak lain berpengaruh dalam memberikan tekanan sosial bagi responden untuk menggunakan tray set green product.

Kontrol perilaku yang dirasakan (PBC) berpengaruh secara negatif dengan minat menggunakan tray set green product, dimana semakin besar kontrol perilaku yang dirasakan maka akan mengurangi minat dalam menggunakan tray set green product. Konstruk PBC merupakan faktor pembatas yang diduga menghambat atau mengurangi minat menggunakan tray set green product. Pada penelitian ini produk ramah lingkungan yang sulit diperoleh, ketersedian informasi mengenai kualitas produk ramah lingkungan yang belum banyak, dan harga produk ramah lingkungan yang relatif lebih mahal akan menghambat atau mengurangi minat dalam membeli tray set green product.

Faktor muatan yang dimiliki oleh ATB, SN dan PBC sebesar 0.27; 0.12 dan 0.15. Artinya, minat menggunakan tray set green product (BI) mampu dijelaskan oleh ATB, SN dan PBC sebesar 0.27; 0.12 dan 0.15. Konstruk ATB memiliki nilai yang lebih besar, dimana hal tersebut menunjukkan bahwa ATB merupakan konstruk dominan yang mampu menjelaskan minat menggunakan tray set green product. Konstruk ATB secara garis besarnya merupakan gambaran atribut-atribut yang terdapat pada tray set green product. Semakin positif penekanan akan kegunaan, manfaat ataupun kesadaran terkait dengan atribut tray set green product, maka akan mendorong minat untuk menggunakan tray set green product.

\section{Pengaruh Behavior Intetion (BI) dengan Variabel Indikatornya}

Variabel laten BI memiliki dua variabel indikator, yaitu minat di masa yang akan datang untuk menggunakan tray set green product (INT31) dan minat di dalam kehidupan sehari-hari untuk menggunakan tray set green product (INT32). Indikator INT31 tingkat signifikansi-nya tidak diketahui karena ditentukan secara default oleh software LISREL 8.7, sedangkan nilai-T dari INT32 adalah signifikan pada taraf nyata 5 persen. Kontribusi faktor muatan dari INT31 dan INT32 adalah 0.97 dan 0.94. Nilai INT31 yang lebih besar menunjukkan bahwa minat di masa yang akan datang untuk menggunakan tray set green product lebih besar kontribusinya bila dibandingkan dengan minat di dalam kehidupan sehari-hari untuk menggunakan tray set green product (INT32).

\section{Preferensi Responden terhadap Kombinasi Tray-Set Green Product}

Responden lebih menyukai tray-set dengan bahan yang kuat, karena tray-set dengan bahan yang kuat akan mampu menampung makanan dan minuman dengan baik. Hal ini tentunya akan membuat responden merasa nyaman dan puas menggunakannya di dalam cabin pesawat. Oleh karena itu nilai kegunaannya lebih tinggi dan lebih disukai responden dibandingkan dengan bahan yang tidak kuat.

Taraf atribut yang memiliki nilai kegunaan tertinggi selanjutnya berdasarkan atribut jenis kemasan adalah kemasan ramah lingkungan. Hal ini berarti tray-set kemasan ramah lingkungan lebih disukai dibandingkan kemasan tidak ramah lingkungan. Hal ini dikarenakan tray-set kemasan ramah lingkungan terbuat dari bahan yang tidak berbahaya bagi kesehatan dan kelestarian lingkungan. Hal ini tentunya akan membuat responden merasa aman dan nyaman di dalam menggunakannya. Oleh karena itu nilai kegunaannya lebih tinggi dan lebih disukai responden dibandingkan dengan kemasan tidak ramah lingkungan.

Berdasarkan atribut bentuk, tray-set dengan bentuk yang menarik lebih disukai responden dibandingkan tray-set dengan bentuk yang tidak menarik. Tray-set dengan bentuk yang menarik tentunya akan menarik perhatian bagi yang menggunakan dan mampu menciptakan rangsangan selera makan di dalam cabin pesawat. Oleh karena itu nilai kegunaannya lebih tinggi dan lebih disukai responden dibandingkan dengan bentuk yang tidak menarik.

Nilai relatif penting (importance) menunjukkan indikasi urutan atribut yang dapat mempengaruhi responden dalam menggunakan tray-set. Nilai relatif penting dengan angka tertinggi menunjukkan bahwa 
atribut tersebut relatif lebih diperhatikan responden dibandingkan atribut-atribut lainnya. Hal ini juga menunjukkan bahwa responden melakukan pilihan (trade-off) pada ketiga atribut ini. Berdasarkan hasil penelitian, nilai relatif penting peringkat pertama dengan angka tertinggi yaitu atribut bahan (41.369 persen), nilai relatif penting peringkat kedua yaitu atribut kemasan $(34.079 \%)$ dan nilai relatif penting peringkat ketiga yaitu atribut bentuk (24.553 persen) dapat dilihat pada Tabel 29. Sisi trade-off responden secara keseluruhan menunjukkan bahwa dari tiga atribut tersebut, responden lebih memilih bahan dibandingkan dua atribut lainnya. Responden lebih memperhatikan atribut bahan yang mereka inginkan terlebih dahulu, kemudian memperhatikan kemasan yang sesuai dengan bahan yang diinginkan, selanjutnya memilih bentuk yang sesuai dengan keinginan.

Bahan tray-set adalah pertimbangan pertama responden untuk menggunakan, oleh karena itu perusahaan sebaiknya mempertimbangkan jenis bahan yang digunakan agar tray-set terbuat dari bahan yang kuat di dalam menjalankan fungsinya yaitu untuk menampung volume makanan atau minuman walaupun untuk sekali penggunaan. Kemasan tray-set adalah pertimbangan kedua responden untuk menggunakan, oleh karena itu perusahaan sebaiknya mempertimbangkan jenis kemasan yang terbuat dari bahan yang aman bagi kesehatan dan mudah didegradasi oleh lingkungan. Selain itu, perusahaan juga sebaiknya memperhatikan bentuk tray-set yaitu diciptakan dengan desain atau bentuk yang menarik dan bernilai seni sehingga mampu menarik perhatian.

\section{Implikasi Manajerial}

Berdasarkan hasil penelitian dapat diberikan beberapa rekomendasi yang dapat diberikan untuk perusahaan yang berkaitan dengan minat konsumen dalam menggunakan tray set green product. Berdasarkan analisis konjoin, perusahaan disarankan untuk memperbaiki tampilan kemasan sesuai preferensi konsumen. Strategi yang dapat ditempuh yaitu dengan menampilkan kemasan yang menarik dan bervariasi dengan informasi produk yang lengkap mengenai keunggulan produk ramah lingkungan.

Hasil analisis deskriptif dalam penelitian ini terkait dengan karakteristik responden berdasarkan demografi, persepsi tentang tray set green product, preferensi. Berdasarkan demografi, terdapat temuan bahwa sebaran responden lebih didominasi oleh usia $<25$ tahun, berjenis kelamin pria, telah menikah memiliki latar belakang pendidikan S1, memiliki pekerjaan sebagai (mahasiswa, ibu rumah tangga, lainnya) dan pengeluaran perbulan $\geq 1000000$.

Berdasarkan SEM, hasil penelitian menunjukkan bahwa hasil penelitian menunjukkan bahwa kepercayaan perilaku menggunakan tray set green product (BB) dan evaluasi konsekuensi terhadap perilaku menggunakan tray set green product (OE) secara nyata dapat menjelaskan sikap terhadap perilaku menggunakan tray set green product (ATB). Konstruk BB dan OE secara nyata mempengaruhi ATB pada tingkat kepercayaan 95 persen. Terkait dengan indikator keyakinan akan pentingnya sertifikat organik (BB5), maka sebaiknya diperlukan pemerintah atau lembaga kesehatan untuk melakukan sertifikasi terhadap tray-set green product. Sertifikat produk ramah lingkungan tentunya sangat diperlukan oleh perusahaan sebagai bukti bahwa tray-set yang dihasilkannya memang memenuhi kriteria sebagai produk yang baik. Sertifikat produk ramah lingkungan juga akan menambah kredibilitas tray set green product yang ditawarkan oleh perusahaan kepada penumpang.

Selain itu, kepercayaan atau persepsi individu adanya dorongan dari pihak-pihak tertentu untuk menggunakan tray set green product (NB) dan anjuran dari pihak-pihak tertentu untuk menggunakan tray set green product secara nyata dapat meningkatkan minat menggunakan tray set green product yang disebabkan oleh pengaruh dari pihak-pihak tertentu (SN). Konstruk NB dan MC secara nyata mempengaruhi SN pada tingkat kepercayaan 95 persen. Harapannya dengan sosialisasi mengenai keunggulan atribut, manfaat sampai kepada kontribusinya terhadap kelestarian lingkungan, maka akan merangsang komponen kognitif dari masyarakat itu sendiri. Semakin tingginya kognitif masyarakat terhadap keunggulan atribut, manfaat, dan kepedulian terhadap lingkungan, maka hal tersebut akan semakin memperkuat kepercayaan masyarakat terhadap tray set green product. Kepercayaan yang tinggi tersebut diharapkan akan meningkatkan minat masyarakat untuk menggunakan tray set green product. Sosialisasi yang dilakukan oleh perusahaan sebaiknya juga didukung oleh ahli lingkungan yang tentunya sangat diperlukan dalam program sosialisasi tersebut dengan memberikan testimoni mengenai keunggulan atribut, manfaat ataupun bentuk kepedulian terhadap lingkungan. Adapun sosialisasi terhadap masyarakat tersebut sebaiknya lebih diutamakan untuk diikuti oleh penumpang Garuda Indonesia. Diharapkan, dengan diberikannya sosialisasi terutama kepada penumpang Garuda Indonesia akan memberikan pengaruh yang lebih besar untuk mendorong minat menggunakan tray set green product. Perusahaan juga dapat 
menginformasikan produknya dengan cara penyebaran leaflet dan melalui media internet yang berisi informasi mengenai keunggulan dan manfaat dari tray set green product itu sendiri.

Hasil penelitian menunjukkan bahwa CB dan PCF memiliki pengaruh yang signifikan terhadap PBC. Nilai faktor muatan untuk CB dan PCF masing-masing sebesar 0.56 dan 0.69. Hal tersebut menunjukkan bahwa memang terdapat faktor yang menghambat ataupun mengurangi minat dalam menggunakan tray set green product. Hasil analisis Conjoint didapatkan bahwa atribut tray set green product yang dipentingkan oleh responden ada tiga, bahan yang kuat, kemasan ramah lingkungan dan bentuk yang menarik. Untuk analisis SEM, sikap terhadap perilaku menggunakan tray set green product (ATB) memiliki kontribusi yang signifikan terhadap minat menggunakan tray set green product (BI). Norma Subjektif (SN) memiliki kontribusi yang signifikan terhadap minat membeli tray set green product (BI); dan kontrol perilaku yang dirasakan (PBC) memiliki kontribusi yang signifikan terhadap minat membeli tray set green product (BI).

\section{Simpulan}

Simpulan yang dapat diambil dalam penelitian ini adalah sebagai berikut: (1).Hubungan sikap terhadap perilaku menggunakan tray-set green product (attitude toward behavior) terhadap pembentukan minat (intention) adalah signifikan. Hal ini menandakan bahwa adanya sikap yang merefleksikan keinginan untuk melakukan perilaku menggunakan tray-set green product, (2).Hubungan norma subjektif (subjective norms) terhadap minat (intention) adalah signifikan. Hal ini menandakan bahwa adanya kekuatan motivasi dari diri sendiri dan orang lain untuk menggunakan tray-set green product, (3).Hubungan kontrol perilaku (perceived behavioral control) terhadap minat (intention) adalah signifikan. Hal ini menandakan bahwa adanya persepsi dari responden mengenai keberadaan hal-hal yang dapat mengurangi atau menghambat minat menggunakan tray-set green product, (4).Preferensi atribut tray-set green product dengan menggunakan analisis conjoint menghasilkan tiga atribut produk yang dianggap penting oleh penumpang, yaitu bahan yang kuat, kemasan ramah lingkungan dan produk yang menarik, (5).Implikasi manajerial berdasarkan hasil penelitian menghasilkan beberapa strategi dan program yang dapat menjadi masukan bagi Garuda Indonesia untuk meningkatkan minat menggunakan tray-set green product. Strategi yang pertama adalah Garuda Indonesia perlu menyediakan produk yang baik dan ramah lingkungan. Program yang dapat dilakukan adalah melakukan penelitian dan pengembangan dengan new product development, melakukan kerjasama dengan konsultan bisnis produk serta perusahaan menyeleksi vendor yang mampu membuat produk sesuai dengan keinginan perusahaan. Aktor yang terlibat dalam hal ini adalah perusahaan, konsultan bisnis dan vendor. Strategi yang kedua adalah sosialisasi ke konsumen tentang keuntungan dan manfaat dari tray-set green product. Program yang dapat dilakukan adalah promosi di boarding dengan banner dan electronic display, promosi melalui flight attendant di cabin dan majalah Garuda serta perusahaan menggunakan ahli atau pakar sebagai icon promosi. Aktor yang terlibat dalam hal ini adalah perusahaan dan periklanan.

\section{Saran}

Saran yang dapat diberikan dalam penelitian ini adalah sebagai berikut:

Berdasarkan hasil penelitian bahwa sikap terhadap perilaku menggunakan tray-set green product, norma subjektif dan kontrol perilaku memiliki nilai signifikan dan berkorelasi positif terhadap minat menggunakan tray-set green product maka: (1).Perusahaan sangat penting untuk meningkatkan minat menggunakan trayset green product di kalangan penumpang. Hal ini tentunya membutuhkan komitmen dan kerjasama yang sinergi diantara perusahaan, vendor, pemerintah dan media massa, (2). Setelah mengetahui tray-set yang seperti apa yang diinginkan oleh responden maka dalam rangka perusahaan Garuda Indonesia ingin meluncurkan tray-set green product agar dapat diterima dan disukai dalam upaya keperdulian terhadap lingkungan maka urutan kriteria yg di inginkan yaitu bahan yang kuar, kemasan ramah lingkungan dan bentuk yang menarik maka hal yang harus dilakukan oleh perusahaan adalah merancang produk sesuai yang diinginkan. Hal ini menunjukkan responden ternyata sudah cukup banyak yang sadar dan mengtahui tentang produk ramah lingkungan yang memiliki manfaat bagi kesehatan dan lingkungan. Selain itu, juga untuk dapat menambah pengetahuan responden maka di produk tersebut dapat dilengkapi secarik kertas yang berisi informasi tentang tray-set green product dan manfaatnya. Tentunya produk juga harus di desain dengan elegan agar terlihat sopan dan penumpang tidak merasa di down grade, dan (3).Terakhir, penting juga untuk diteliti mengenai perilaku penumpang yang telah menggunakan tray-set green product untuk melihat tingkat kepuasan dan juga loyalitasnya. 


\section{DAFTAR PUSTAKA}

Aaker, D.A. \& Kumar V, Day George S. 2001. Marketing Research. Sixth edition. New York, John Wiley $\&$ Sons, Inc.

. 2006. Behavioral Intentions Based on The Theory of Planned Behavior: Brief Description of The

Theory of Planned Behavior. J University of Massachusetts. Amherst.

Ampuero, O et al. 2006. Consumer Perceptions of Product Packaging. Journal of Consumer Marketing. Emerald Group Publishing Limited.

Assael, Henry. Consumer Behviour and Marketing Action, $6^{\text {th }}$ edition. Booson: Wadshweet Inc.1998.

Astuti, RK. 2000. Kajian Konsumen Terhadap Peranan Kemasan dan Label Sebagai Elemen Strategi Pemasaran (Studi Kasus Kacang Tanah Olahan Kelompok Perusahaan Garuda Food. Tesis. Program Studi Magister Manajemen Agribisnis. Institut Pertanian Bogor. Bogor

Cheolh Y. 2010. Theory of Planned Behavior and Ethics Theory in Digital Piracy : An Integrated Model. $J$ of Business Ethics. 100: 405-417.

Danger, EP. 1992. Memilih Warna Kemasan, Pedoman Aplikasi. Jakarta: PPM.

Engel JF, Blackwel RD Miniard PW. 1994. Perilaku Konsumen. Jakarta: Bina Aksara.

Engel, J.F., R.D Blackweel and P.W. Miniard. 1995. Consumer Behaviour. 8 th Edition. The Dryden Press. Orlando, Florida.

Evans, Jr, Burry B. 1997. Principall of Marketing. Prentice Hall.

Ferdinand, A. 2002. Structural Equation Modelling dalam penelitian Manajemen. Aplikasi Model-model Rumit dalam Penelitian untuk Tesis Magister dan Disertasi Doktor. Edisi 2. BP UNDIP Semarang

Kusminanti Y. 2005. Sumbangan sikap, norma subjektif dan perceived behavioral control terhadap intensi untuk menggunakan helm pada pekerja konstruksi bangunan [tesis]. Depok: Program Pascasarjana, Fakultas Psikologi, Universitas Indonesia.

Lin, RJ, Kim HT, Gen Y. 2012. Market Demand, Green Product Innovation and Firm Performance: Evidence From Vietnam Motorcycle Industry. Journal Of Cleaner Production XXX (2012) 1-7.

Nazir, M. 2003. Metode Penelitian. Cetakan kelima. Ghalia Indonesia. Jakarta.

Paramawati, R. 2000. Perkembangan Teknologi Kemasan Pangan (Tinjauan dari Sudut Filsafat). Program Studi Ilmu Pangan Pascasarjana Institut Pertanian Bogor.

Parasuraman A, Zeithaml VA, Berry L L. 1990. Delivering Quality Service, Balancing Customer Perceptions and Expectations. The Free Press: New York.

Ratri,2005. Analisis Persepsi dan Sikap Konsumen terhadap Minuman Teh dalam Kemasan Botol Merek Freshtea di Kota Bogor. Tesis. Program Pascasarjana Magister Manajemen Agribisnis. Institut Pertanian Bogor. Bogor.

Sugiyono. 1999. Metode Penelitian Administrasi. Bandung: Alfabeta.

Suharjo, B. 2004. Customer Satisfaction Research and Data Analysis. MARS.

Supartono W, Handayani PE, Suyitno. 1996. Analisis Pengambilan Keputusan Konsumen Terhadap Pemilihan Ukuran Kemasan Produk Susu. Skripsi. Program Studi Teknologi Industri Pertanian. Universitas Gajah Mada. Yogyakarta.

Tjiptono, F. 1999. Strategi Pemasaran. Yogyakarta: ANDI.

Wells, W, Prensky D. 1996. Consumer Behaviour. New York: John Wiley \& Son

Wibowo, B. 2002. Green Consumerism dan Green Marketing : Perkembangan Perilaku Konsumen dan Pendekatan Pemasaran. Usahawan, No. 6 Th XXXI Juni, pp : 12-15.

Wirya, I. 1999. Kemasan Yang Menjual. Jakarta: PT. Gramedia Pustaka Utama. 